\title{
Creating and shaping the marketplace?
}

The festive atmosphere at this year's annual meeting of the Biotechnology Industry Organization (BIO), held in Houston, was a far cry from the doom and gloom of three years before, or the quiet desperation of even 18 months ago. The infusion of cash into the market in 1996 has steadied people's nerves, as has the arrival of successful new products, like Genetics Institute's BeneFix for hemophilia, Advanced Tissue Sciences' Dermagraft-TC for severe burns, and Biogen's Avonex for multiple sclerosis. Even product failures-of which there have been more than a few (see p. 610)-haven't brought the whole sector crashing down. With products on or approaching the market, and a cluster of new drug discovery technologies promising the possibility of more, attention has now turned to how to accelerate market acceptance of biotechnology goods and services.

In his plenary address to the conference, BIO chairman Henri Termeer cautioned that obstacles still lie ahead. In particular, he spoke of the need to change healthcare providers' perception of biotechnology products as both expensive and experimental: "Until now, we have been poor at connecting with the market," he told the delegates, "The challenge that lies ahead is creating and shaping our marketplace."

Termeer went on to talk of the need "to double the market return of biotechnology products," particularly in view of the current annual ( $\$ 8$ billion) rate of R\&D spending. He argued that the number of products that biotechnology gets on the market will be increased by targeting the healthcare institutions and organizations that evaluate and adopt new therapies. "Where are the HMOs, the hospital centers, the patient organizations, and insurers?" he asked, looking around the conference hall. "We must foster links with them to encourage adoption of the innovations that biotechnology is bringing forth."
Termeer has a special perspective-in addition to being BIO's chairman, he is president and CEO of Genzyme, a top-tier biotechnology company. As our survey in May indicated (Nature Biotechnology 15:412, 1997), companies such as Genzyme with products on the market and a positive cash flow are the exception rather than the rule. Most biotechnology companies do not have the financial means or the clout to promote and sell their products in today's complex health management environment. But they do business with businesses that do. And that is what strategic partnering is for.

In fact, with increased outlicensing of products and technologies, pharmaceutical companies are already taking on board the cost of manufacturing and marketing biotechnology products. One estimate places big pharma spending on the marketing of a single drug at about twice that spent for research and development. Pharmaceutical companies have also reoriented themselves to sell effectively to newly cost-conscious buyers and can afford to take the necessary steps to accelerate drug acceptance (e.g., incorporating extra trial data to prove drug cost-effectiveness, efficacy, and safety).

So while Termeer is right in emphasizing the importance of understanding biotechnology's changing marketplace at this juncture-more than 280 biotechnology products are in late-stage human trials, a watershed in terms of potential returns for patients and investors-spending time, money, and effort to court healthcare organizations is not an appropriate strategy for most biotechs. Although they should clearly be aware of the markets they hope to reach, biotechnology companies would do better to continue to concentrate on what they do best-develop innovative technologies and products. Market shaping is considerably less precise and much more expensive than drug discovery.

\section{Chickens, cows, bulls, and bears}

The foul odor that used to pervade the small village of Gillingham in England when the wind blew from the south was horse skin and bones, bulk boiled to make glue. The factory has been closed for over 30 years now. The raw material-old nags--was already a precious commodity (well rare anyway) in the 1960 s, even in a rural community where horses still worked the land. And the collagen compote that was the product of the horse broth has long since been replaced in all but the most arcane of uses (reproduction bookbinding, for instance) by stickier and more aged-animal-friendly chemical products.

Unhappily, the ethos that created that flawed industrial idyll of yesteryear lives on. Reincarnated, for instance, in Colloral, a product developed by Autoimmune, a Lexington, Massachusetts-based company that, justifiably or not, wears the biotechnology mantle.

Colloral, a type II collagen purified from the cartilage of the sternums of chickens, has been touted as an oral treatment for rheumatoid arthritis. Just drink a few hundred micrograms in your morning orange juice. Unfortunately for Autoimmune's believers, phase III trials concluded in May did not support the claim. This is surprising, given the enormous amount of prior art accruing to the successful use of chicken soup. And only the month before, Autoimmune suffered another disappointment. Myoral, an encapsulated treatment for multiple sclerosis, failed in its clinical trial. Myoral, a brawny drug-that's brawn as in brain pâté, a fine English delicacy from the pre-BSE days-is 300 micrograms of pasteurized, quality-controlled myelin purified by ultracentrifugation from cow brain white matter. One a day before breakfast.

Ultracentrifuged cow brains and chicken gristle: Biotechnology drugs? Even in a postgenomic, combinatorially evolved, antisense era, no small number of investors thought so. Judging from the precipitous drop in the company's stock price following the clinicals, the two products together were valued at around $\$ 250$ million.

This modern Aesop's story of processed meat masquerading as high-tech pharmaceuticals seems as if it ought to contain a moral, perhaps somber warning against putting blind trust in labels like "biotechnology drug." But given the predictable nature of some biotechnology investors, a more practiced eye might see it as simply another illustration of the eternal wisdom of US circus impresario Phineas T. Barnum- "there's a sucker born every minute"-and with a wink, move on. 